\title{
Possibilities and challenges of inclusive economic growth in countries
}

\author{
Mavluda Askarova ${ }^{1, *}$, Toir Saddulaev ${ }^{1}$, and Bunyod Radjabov ${ }^{1}$ \\ ${ }^{1}$ Tashkent State University of Economics, 49 Islam Karimov Avenue, Tashkent, 100003, Uzbekistan
}

\begin{abstract}
The purpose of the study of this topic is inclusive growth and inclusive economic growth in the territory of the Republic of Uzbekistan. Using the theoretical method of analysis, the results of the developed countries of the world, as well as the state of the economy of Central Asia, in particular the Republic of Uzbekistan, are analyzed. The observation method reveals the impact of inclusive economic growth on the standard of living and well-being of the world's population. The article compares data on the impact of the global economic and financial crisis on the economies of the world and the Republic of Uzbekistan, which began in 2019, and its consequences are reflected on inclusive economic growth. Projections of social development up to 2030 are made, this development factor plays an important role in inclusive economic growth. The result of this study is the conclusion about the importance of the inclusive growth index, which can replace the GDP indicator. Index of inclusive analysis of information on various aspects of society. This index can also be used to predict the socioeconomic development of the state.
\end{abstract}

\section{Introduction}

In recent years, inclusive economy and inclusive economic growth have become a topical topic; this topic is discussed in international organizations such as the UN, the World Bank, and the World Economic Forum. There are many interpretations of inclusive growth, but there is no consensus yet. The UN's interpretation seems more reasonable, it implies fair development, with the participation of all segments of the population on equal terms, including the "disadvantaged" ones, in the process of economic growth and distribution of profits from increased prosperity in monetary and other terms. At the same time, such categories of the population as youth, women, freelance workers, the elderly, and migrants should feel the benefits.

Uzbekistan's reforms should focus on the following main components, namely, building up high-quality investments, maintaining economic and financial stability, and fighting corruption.

Various aspects of Inclusive economic growth have been studied and researched by many scientists, as well as many projects have been implemented in this field. Including G.Bolotaulo, E.Hyop and L.Donghyun (Fiscal Policy for Inclusive Growth, 2014); C.Adamba, K.Alatinga (Social and Health Policies for Inclusive Growth, 2015); Dev, S.M.

\footnotetext{
${ }^{*}$ Corresponding author: sb.i.1@mail.ru
} 
(Inclusive Growth in India. Agriculture, Poverty, and Human Development, 2008); Dollar, D. and Kraay, A. (Growth is good for the poor, 2002); Heintz, J. (Informality, inclusiveness and economic growth, 2012) discuss the advantages and disadvantages of inclusive growth. K.P. Kannan (How inclusive is inclusive growth in India?, 2012); T. and Tabellini, G. (Is inequality harmful to growth?, 1994); Thomas, V. (Inclusive growth: From desirable to essential, 2011) discusses the possibilities of development and inclusive growth. In this article highlights the opportunities and challenges of inclusive economic growth in countries.

\section{Definition of inclusive growth in the activities of other international organizations}

The World Bank has been working for many years on the concept of inclusive growth [1]. In the previous approach, inclusive growth implied the pace and form of economic growth, and economic growth led to rapid growth, which is necessary to reduce absolute poverty and reduce the wide range of needs across sectors. In the long run, part of the country's workforce has focused on inclusive growth in this perspective as follows: effective employment has been achieved instead of employment or income distribution. Increasing employment, creating new jobs and incomes, increasing productivity, raising the wages of workers and the incomes of the self-employed, and so on. Recently, the World Bank developed the Framework for Common Welfare. The concept of overall well-being encompasses the two elements of economic growth and equality through a new indicator that tracks income growth, and the Asian Development Bank (ADB) has developed a corporate strategy (Strategy 2020) to promote it among the lower 40 percent of the population. chose inclusive economic growth as one of its main goals. In this context, the concept of continued inclusive growth, in addition to broad growth, is that "growth not only creates new economic opportunities, but also provides them with equal access to opportunities created for all segments of society, especially the poor. includes ".

An episode of revenue growth is considered "inclusive" if it:

- focusing on the ability of all members of society to participate, the poor and the poor to participate in growth (the 'non-discriminatory' side of growth). This means that the "process" of growth will be the focus;

-this is particularly important for the development of economic opportunities, including education, health, nutrition and social integration, associated with a reduction in inequality in uncertain measures of well-being. The "gap reduction" side of inclusive growth. This means focusing on the "results" of growth.

The UN recently changed the name of the International Poverty Center in Brazil to the Center for International Politics. On Inclusive Growth (IPC-IG), its work is based on better performance by equal societies development. In the perspective of UNDP, inclusive growth is seen as both a result and a process. On the one hand, this ensures that everyone is involved in the growth process, both in terms of decision-making. Inclusive growth, on the other hand, is growth whose benefits are evenly distributed. Inclusive growth implies participation and profit sharing. The Europe 2020 Strategy includes the concept of "Inclusive Growth". Inclusive growth in this strategy is the modernization, transformation and integration of labor markets, training and social protection systems to provide people with high levels of employment, invest in their skills, fight poverty and help people expect and manage. concepts such as community building. It is also important that the benefits of economic growth spread to all sectors. The Alliance, including its external regions, will thus strengthen regional solidarity. Ensuring that growth and life cycle opens up opportunities for everyone. 
Over the past thirty years, the development of the world economy has been marked by broad regulation of markets - especially financial and foreign exchange markets - in both rich and poor countries, the outdated public sector and the expansion of creative opportunities are among the growing sectors. social, cultural and political life. This is the period described as "Hyperglobalization" [2].

Hyperglobalization has resulted in a major change of government, with more capital being used than labor. This has led to more and more asymmetries, through which more concentrated and strong transnational units working through international trade and financial relations and, in many cases, weakened governments, have occurred in countries. Other features of globalization include financial financing. The economy, growing inequality, high market concentration, rent-seeking and ever-increasing debt, and more. The global financial crisis of 2008-2009 (GFC) to some extent slowed down this process of hyperglobalization, which did not negate any of them. Governments have embraced saving private investors with taxpayers 'money and net economic savings, and have violated the social policy envisaged by this: they continued with "business as usual" to help the most vulnerable. Hyperglobalization has intensified the political and technocratic grievances of the people, as well as provoked a backlash. Since Brexit, the choice in various forms and at different levels, through the "yellow vests" and "trade wars" in France, to mention a few of the school strikes, as well as the movement for appropriate climate action is the most comprehensive project and universal in history.

\section{Results}

The issue of inclusive growth is relevant for the Eurasian economy. Member States of the Union (EAEU) (Republic of Armenia, Belarus, Republic of Kazakhstan, Kyrgyz Republic and Russian Federation). According to Article 4 of the Treaty on Eurasia, the economic union, one of the main objectives of the union is to improve the living standards of the population, the conditions for sustainable economic development of these member states. The responsibility to the supervisory authorities of the EU Member States for these additional areas applies to all citizens of each country. This is because the EU's commitment to implement long-term scenarios of economic development could lead to a deterioration in the current quality of life. In addition, the external economic environment has generally been unfavorable for EU member states in recent years. In the past, there was a need to create more fully, the vision of the problems facing the population in the global context, the turmoil of the economy and the intensification of internal problems focused on the development and implementation of integration measures and actions.

\subsection{Problems of achieving more financial inclusion and future research directions}

The evidence suggests [2], financial inclusion is the ability to manage operations through the use of a formal financial system to enable people to create day-to-day financial opportunities to conduct operations more efficiently and securely and to expand their investment and financial risk. This is especially true for people: the poorest 40 percent of the population needs help in the household. However, not all financial products are equally effective in achieving development goals such as poverty reduction and inequality. Current evidence suggests that the biggest impact comes from the savings account - if they exist, they are cheap and serve a clear purpose. The impact of microcredit research shows mixed and rare effects, some research shows that insured people have invested in risky and highyield technologies, but little is known about its impact on well-being. 
Over the past two years, the number of publications on measuring the impact of financial inclusion has been growing rapidly. However, the study of the impact of different dimensions of financial inclusion on economic development still has a long way to go. In particular, there are currently several studies on payments, savings, and insurance, and it is suggested that they should be even better.

The results of randomized controlled trials are somewhat ambiguous. Positive conclusions may apply to other countries and groups of people. For example, it is not known whether a savings product that benefits women in the Kenyan market will benefit a male farmer. Repetition of successful interventions in a variety of activities answers such questions and leads to clarification of situations that improve financial inclusive living conditions. Similarly, research is needed to understand why more financial inclusion may have a beneficial effect on some. For example, available evidence of financial inclusion can have a significant impact on product design, including prices, demand and development outcomes.

Our analysis shows that [3], According to Professor Tursin Shodiyev, the development of the economies of small countries, including Uzbekistan, will cover economic losses in 5 or 6 months, this year's GDP growth rate will be 1.2-1.5\%, and next year - 7\%., Increases by $0-7.2$ percent. The global crisis resulted from the global spread of the coronovirus pandemic that erupted in late 2019 in the city of Uwan in the People's Republic of China. It differs from the world crises in various respects and its negative impact on the economy is becoming very strong. In economic terms, this pandemic is an external "shock" to aggregate demand (AD) and Forecasts and aggregate supply (AS), macroeconomic stability (external shock), which outperform previous economic indicators in terms of scale and damage much different crises. This crisis occurred suddenly in 185 countries around the world. This affected both aggregate supply and aggregate demand at the same time. The emerging open global economy and national economy have been in a closed form for several months. In the world economic literature, little experience has been gained in identifying and mitigating the negative impact of the coronovirus pandemic on the world and regional economies, and the topic has not been studied systematically. The purpose of this article was to partially study the effects of the spread of the coronovirus pandemic on global and regional skills and to predict the effectiveness of measures to mitigate its effects in our country. and positive silences in the national economy, signs of sustainable development. Its high rates are observed in China, Tajikistan, Armenia and Uzbekistan, low rates are observed in the United States, Great Britain and the Russian Federation, and in recent years the economic growth rate in the world economy has averaged around 3 percent. The gross income of the world economy in 2019 was \$ 84.5 trillion, including \$ 20.6 (share 24.4\%), the People's Republic of China 13.1 (share 15.6\%), Germany 3.9 (4)., $6 \%), 2.8(3.3 \%))$ of the United Kingdom, $1.5(1.9 \%)$ of Russia and South Korea (Table 1).

Looking at the table, per capita income declines are projected in the United States $(\$$ 1892), followed by Germany (1413), the United Kingdom (1216), South Korea (\$918), Russia (311) and China. (284dol). The total damage in the Republic of Uzbekistan amounted to 2.1 billion soums. That's in U.S. dollars and \$ 60 per capita. Some countries are distributing money to cover the loss of income of the population. However, the government of the Republic of Uzbekistan makes an alternative decision, and through the general movement of "support and assistance", enterprises and public organizations hold charity events for low-income families. The participation of enterprises in the general movement "Support and Assistance" is not an attempt by the state to reduce the damage caused to entrepreneurs by the crisis, but an attempt to correct the situation in which this general demand is falling. Because at a time when aggregate supply is declining, increasing aggregate supply by distributing money to the population increases inflation and 
the population may not benefit from it at all. The participation of enterprises in general activities benefits them.

Table 1. The state of the world economy and economic cooperation with Uzbekistan in 2018.

\begin{tabular}{|c|c|c|c|c|}
\hline Countries & $\begin{array}{c}\text { Area,thousand } \\
\text { sq.km }\end{array}$ & $\begin{array}{c}\text { Population } \\
\text { the number } \\
\text { (mln. man) }\end{array}$ & $\begin{array}{c}\text { GNP } \\
\text { (bln.fertilized) }\end{array}$ & $\begin{array}{c}\text { Population } \\
\text { per capita } \\
\text { income } \\
\text { (fertilized })\end{array}$ \\
\hline Usa & 9831.6 & 327.2 & 20636.3 & 63080 \\
\hline Great British & 243.6 & 68.5 & 2777.4 & 41770 \\
\hline Germany & 357.6 & 82.9 & 3905.3 & 47090 \\
\hline Russia & 17098.3 & 144.5 & 1501.7 & 10230 \\
\hline China XR & 9562.9 & 1392.7 & 13181.4 & 9460 \\
\hline South Korea & 100.3 & 51.6 & 1580.1 & 30600 \\
\hline Kazakhstan & 2724.9 & 18.3 & 147.6 & 8070 \\
\hline Uzbekistan & 447.4 & 33.0 & 66.5 & 2020 \\
\hline Kyrgyzstan & 200.0 & 6.3 & 7.7 & 1220 \\
\hline Tajikistan & 141.4 & 9.1 & 9.2 & 1010 \\
\hline Turkmenistan & 488.1 & 5.9 & 39.4 & 6740 \\
\hline Belarus & 207.6 & 9.5 & 53.8 & 5670 \\
\hline Armenia & 29.7 & 3.0 & 12.5 & 4230 \\
\hline Turkey & 785.4 & 82.3 & 858.1 & 10420 \\
\hline World on & 132025.2 & 7594.3 & 84478.9 & 11124 \\
\hline
\end{tabular}

\section{Discussion}

\subsection{Modern global social and economic problems}

For the last few decades decrease in rates of world economy growth was matched by increasing inequality in income and accumulated wealth among world's population [4]. There are bases to believe that the system of income distribution affects not only stability of society, but growth rates of world economy as well. Aggravation of economic inequality leads to access restriction to education for lower-income population strata that has negative impact on development of the human capital as a main resource of a modern economic system $[5,6]$. The problem of the growing inequality in income and accumulated wealth 
among world's population is closely related to demographic processes which happen in the developing and developed countries.

Today the steady trend of decrease in rates of natural population growth in the developed countries is observed. It confirms the oncoming demographic crisis in a number of countries. Thus, according to forecasts of United Nations Department of Economic and Social Affairs natural increase of the cumulative population of the most developed regions (Europe, North America, Australia/New Zealand and Japan) will continue to decrease up to the period of 2025- 2030 when the indicator of natural increase takes negative value and will mark the beginning of depopulation. Long-term decrease in rates of natural population growth combined with high standard of living and the growing indicator of life expectancy at birth triggers changes in population age structure, as a result it leads to increased demographic pension expenditure burden on the population of working-age (Tables 2, 3, 4).

Table 2. The rates of natural population growth in regions of the world calculated on the basis of information from the UNDESA (1985-2030).

\begin{tabular}{|l|c|c|c|c|c|c|c|c|c|}
\hline \multirow{2}{*}{$\begin{array}{l}\text { Regions } \\
\text { or area }\end{array}$} & \multicolumn{7}{|c|}{ Rate of natural population growth (per 1,000 population) } \\
\cline { 2 - 9 } & $\mathbf{1 9 9 0}$ & $\begin{array}{c}\mathbf{1 9 9 0 -} \\
\mathbf{1 9 9 5}\end{array}$ & $\begin{array}{c}\mathbf{1 9 9 5 -} \\
\mathbf{2 0 0 0}\end{array}$ & $\begin{array}{c}\mathbf{2 0 0 0 -} \\
\mathbf{2 0 0 5}\end{array}$ & $\begin{array}{c}\mathbf{2 0 0 5 -} \\
\mathbf{2 0 1 0}\end{array}$ & $\begin{array}{c}\mathbf{2 0 1 0} \\
\mathbf{2 0 1 5}\end{array}$ & $\begin{array}{c}\mathbf{2 0 1 5}-\mathbf{2 0 2 0} \\
\mathbf{2 0 2 0}-\end{array}$ & $\begin{array}{c}\mathbf{2 0 2 5}- \\
\mathbf{2 0 3 0}\end{array}$ \\
\hline $\begin{array}{l}\text { More } \\
\text { developed } \\
\text { regions }\end{array}$ & 4.2 & 2.3 & 1.0 & 0.7 & 1.3 & 1.1 & 0.6 & 0.1 & -0.5 \\
\hline $\begin{array}{l}\text { Less } \\
\text { developed } \\
\text { regions }\end{array}$ & 21.8 & 18.6 & 16.3 & 15.3 & 14.8 & 14.1 & 12.9 & 11.6 & 10.4 \\
\hline $\begin{array}{l}\text { Least } \\
\text { developed } \\
\text { countries }\end{array}$ & 28.1 & 26.8 & 26.6 & 26.3 & 26.0 & 25.2 & 24.2 & 23.0 & 21.8 \\
\hline
\end{tabular}

Table 3. Life expectancy at birth in regions of the world calculated on the basis of information from the UNDESA (1985-2030).

\begin{tabular}{|l|r|c|c|c|c|c|c|c|c|}
\hline \multirow{2}{*}{ Regions or area } & \multicolumn{7}{|c|}{ Life expectancy at birth for both sexes } \\
& \multicolumn{1}{|c|}{$\mathbf{1 9 8 5}$} & $\mathbf{1 9 9 0}$ & $\mathbf{1 9 9 5}$ & $\mathbf{2 0 0 0}$ & $\mathbf{2 0 0 5}$ & $\mathbf{2 0 1 0}$ & $\mathbf{2 0 1 5}$ & $\mathbf{2 0 2 0}$ & $\mathbf{2 0 2 5}$ \\
& - & - & - & - & - & - & - & - & - \\
& $\mathbf{1 9 9 0}$ & $\mathbf{1 9 9 5}$ & $\mathbf{2 0 0 0}$ & $\mathbf{2 0 0 5}$ & $\mathbf{2 0 1 0}$ & $\mathbf{2 0 1 5}$ & $\mathbf{2 0 2 0}$ & $\mathbf{2 0 2 5}$ & $\mathbf{2 0 3 0}$ \\
\hline More developed regions: & 73.94 & 74.16 & 74.80 & 75.59 & 76.93 & 78.43 & 79.28 & 80.12 & 80.93 \\
\hline Less developed regions & 61.32 & 62.52 & 63.78 & 65.47 & 67.36 & 69.10 & 70.34 & 71.39 & 72.37 \\
\hline $\begin{array}{l}\text { Least developed } \\
\text { countries }\end{array}$ & 50.64 & 51.54 & 53.81 & 56.43 & 59.84 & 62.66 & 64.57 & 66.10 & 67.50 \\
\hline
\end{tabular}

Table 4. The pension demographic burden in most developed regions of the world calculated on the basis of information from the UN DESA (1985-2025).

\begin{tabular}{|l|c|c|c|c|c|c|c|c|c|}
\hline \multirow{2}{*}{$\begin{array}{l}\text { Regions or } \\
\text { area }\end{array}$} & \multicolumn{7}{|c|}{ Old-age dependency ratio } \\
\cline { 2 - 10 } & $\mathbf{1 9 8 5}$ & $\mathbf{1 9 9 0}$ & $\mathbf{1 9 9 5}$ & $\mathbf{2 0 0 0}$ & $\mathbf{2 0 0 5}$ & $\mathbf{2 0 1 0}$ & $\mathbf{2 0 1 5}$ & $\mathbf{2 0 2 0}$ & $\mathbf{2 0 2 5}$ \\
\hline $\begin{array}{l}\text { More } \\
\text { developed } \\
\text { regions }\end{array}$ & 17.5 & 18.7 & 20.4 & 21.2 & 22.6 & 23.7 & 26.7 & 30.2 & 33.8 \\
\hline
\end{tabular}

In less developed and the least developed regions of the world (Africa, Asia except Japan, Latin America and the Caribbean plus Melanesia, Micronesia and Polynesia as 
defined by the United Nations General Assembly) it is possible to observe quite different processes. In less developed countries with the low and average levels of income usually high rates of natural growth of population is accompanied with low standard of living and a weak health care system $[7,8]$. The indicator of life expectancy at birth in such states is much lower than in the developed countries. It implies specific changes of age structure of the population and increase in child demographic burden on a working-age population (Table 2,3,5). The majority population of such regions are young people of working-age. When a national economy is not able to provide high employment and a decent standard of living for citizens they tend to migrate for search of better conditions for life and selfrealization.

The contrasting differences of demographic processes in developed and developing countries added to increasing economic inequality within the last three decades has led to growth of international migration in absolute and relative numbers to the total population of the planet [9]. International migration is a complex phenomenon which directly influences process of human capital formation and can render both positive and negative impact on national economic systems [10]. International migration may partially contribute to the solution of the problem of economic inequality, as it positively influences the income of immigrants.

Table 5. The child demographic burden in regions of the world calculated on the basis of information from the UN DESA (1985-2025).

\begin{tabular}{|l|c|c|c|c|c|c|c|c|c|}
\hline \multirow{2}{*}{ Region or area } & \multicolumn{7}{|c|}{ Child dependency ratio } \\
& \multicolumn{7}{|c|}{ (ratio of population aged 0-14 per 100 population } \\
\cline { 2 - 10 } & $\mathbf{1 9 8 5}$ & $\mathbf{1 9 9 0}$ & $\mathbf{1 9 9 5}$ & $\mathbf{2 0 0 0}$ & $\mathbf{2 0 0 5}$ & $\mathbf{2 0 1 0}$ & $\mathbf{2 0 1 5}$ & $\mathbf{2 0 2 0}$ & $\mathbf{2 0 2 5}$ \\
\hline $\begin{array}{l}\text { Less developed } \\
\text { regions }\end{array}$ & 64.3 & 61.1 & 57.8 & 53.1 & 47.7 & 44.5 & 43.0 & 41.7 & 40.1 \\
\hline $\begin{array}{l}\text { Least developed } \\
\text { countries }\end{array}$ & 86.3 & 85.6 & 83.0 & 80.2 & 77.5 & 75.1 & 71.3 & 67.1 & 63.2 \\
\hline
\end{tabular}

Today the world community has to apply new approaches to the problem of economic growth in order to achieve acceleration of economic development and find solutions to global social and economic problems. One of those can be the inclusive approach, which is the cornerstone of the concept of inclusive growth. It is impossible to create and implement a new concept of economic growth targeted for increase of GDP rates through the solution of social problems without methodological and statistical base. The new system of social and economic development level assessment of the state which received the name Inclusive Development Index can take this place [10].

\subsection{Prospects of the index of inclusive development application}

The main objective of the index of inclusive development is broad disclosure of economic information about the state to all interested persons and the public for the benefit of economic development of the country. This index is calculated on the basis of 12 indicators divided in three groups (Growth and Development; Inclusion; Intergenerational Equity and Sustainability), each of which reflects various aspects of social life [11,12]. The index of inclusive development initially was developed within the concept of inclusive growth, however, it can find application outside the separate concept.

When forming with the subsequent implementation the new concept of economic growth directed specifically to GDP growth rates increase through the solution of social and economic problems, application of this index can be in high demand. As the system of assessment of social and economic level of development of the country, the index of 
inclusive development gives the most comprehensive information on a state of national economic system as well as society in general. Some common and widely accepted indicators of economic development of the country such as GDP can not provide full information for working out effective policy of the state. No doubt, GDP is the most widely used indicator of economic development of the state, the convenient instrument for accounting the size of economy today. However, it is incorrect to use GDP as the main reference point while planning social and economic development policy of the country at present, because GDP indicator for the purpose has a number of restrictions. [13]

As GDP indicator measures economy size is does not always adequately reflect quantitative characteristics of a modern economic system. Scientific and technical progress contributed to creation of essentially new types of goods and services and to substantial enhancement of ways of information and resources exchange [14]. Using the existing methods of collecting statistics it is getting increasingly harder to account for some specific transactions or to carry out financial assessment of new types of economic activity. As an example, consider the market of crypto currencies which is difficult to account and regulate. Another example is investment accounting for intangible assets becoming more and more relevant today. In modern economy long-term investments in such valuable resources as information, knowledge, scientific $R \& D$ and human capital can hardly be fully reflected in GDP [15]. As an indicator of social and economic level of development of the country GDP also has certain restrictions. It does not measure the system of product distribution, therefore GDP can not be used as a measure of country's prosperity. Besides, GDP does not fully measure ecological and social factors of economic growth.

\section{Conclusion}

The essence of the earlier stated boils down to the idea that GDP can not be effectively used to adequately estimate the level of social and economic development of the modern state, as it does not reflect the influence of non-economic factors on an economic system and society in general. On the opposite, the index of inclusive development provides complex information on various aspects of society. In the long term perspective this index can be used in forecasting of social and economic development of the state. Active application of a new system of assessment of economic development by the international community will promote changes in the social and economic policy of states, stimulate international economic integration and development of methodological base of national and international statistical institutions. Taken together, the index of inclusive development opens new opportunities for working out, development and implementation of new concepts of economic growth, such as inclusive growth, sustained economic growth, social and economic problem solution in developed and developing countries. Where state (financial) capacity to redistribute is limited, broader institutions, at national and international level, such as tax regimes, competition authorities, consumer organizations, and trade negotiations and institutions, impact growth at least as much as growth, whether it is inclusive and whether it can be sustained.

\section{References}

1. http://www.eurasiancommission.org/ru/act/integr_i_makroec/dep_makroec_pol/Docu ments/Inclusive_growth_in_EAEU_Member.pdf

2. https://www.oecd-ilibrary.org/docserver/5jrqppxjqhg4en.pdf? expires $=1606386251 \& \mathrm{id}=\mathrm{id} \&$ accname $=$ guest $\&$ checksum $=7 \mathrm{D} 7083 \mathrm{D} 36063 \mathrm{DE} 7$ A46241EF3987DC96B 
3. http://documents1.worldbank.org/curated/en/403611493134249446/pdf/WPS8040.pdf.

4. https://www.usajournalshub.com/index.php/tajiir/article/view/746/700

5. https://doi.org/10.1051/shsconf/20196205002

6. G.A. Marrero, J.G. Rodríguez, Inequality of opportunity and growth, Journal of Development Economics 104, 107- 122 (2013) DOI: 10.1016/j.jdeveco.2013.05.004

7. A. Mason, R. Lee, J.X. Jiang, Demographic dividends, human capital, and saving, The Journal of the Economics of Ageing 7, 106-122 (2016) DOI: 10.1016/j.jeoa.2016.02.004

8. J.E. Stiglitz, A. Sen, J.-P. Fitoussi, Report by the Commission on the Measurement of Economic and Social Progress (2009) URL: http://ec.europa.eu/eurostat/documents/118025/118123/Fitoussi+Commission+report (accessed 24.10.2020)

9. M.J. Boskin, Economic growth is the answer, Project syndicate (2019) Mode of access: https://www.project-syndicate.org/commentary/growth-technology-living-standardsby-michael-boskin-2019-12

10. V.B. Andrievskaya, Efficiency of public administration as a necessary prerequisite for inclusive economic growth, Ideas and ideals 2, 1 (23), 90-101 (2015)

11. I.V. Zenkova, The main fundamental prerequisites for the formation of effective employment in economic systems for inclusive economic growth, Bulletin of the Peoples' Friendship University of Russia, Series: Economics 25, 3, 333-342 (2017)

12. Kh.A. Khakimov, Methodological approaches to the assessment of inclusive growth, Science and World 2, 5 (33), 159-162 (2016)

13. N.A. Novitskiy, Development of the strategy of innovative economic growth in the context of a new technical order6 Moscow University Bulletin named after S. Yu. Witte. Series 1: Economics and Management 3 (18), 66-74 (2016)

14. I.S. Voronina, Yu.V. Leonova, Information economy as the basis of economic growth and increasing the level of welfare of citizens, Scientific and educational potential of youth in solving urgent problems of the XXI century 7, 6-7 (2017)

15. K.B. Kostin, Drivers of growth of the world economy, News of the St. Petersburg State University of Economics 6 (108), 19-24 (2017) 